Niklas Altermark

\title{
Hur legitimeras socialpolitiska
} besparingar?

\section{Konstruktionen av personlig assistans som ett "kostnadsproblem"}

How are cutbacks in social policy legitimized? The construction of personal assistance as a "cost problem"

This article seeks to explain how current austerity measures targeting personal assistance for people with disabilities are legitimized. Following the work of Bacchi and Ingram and Schneider, I argue that the construction of personal assistance as a "cost problem" is absolutely central, where assistance-users are depicted as "over-users" and potential fraudsters, while personal assistance companies are described as solely motivated by maximizing profits. However, upon closer scrutiny, the actual cutbacks that the government has implemented do not match how the "cost problem is constructed"; the policies aimed to reduce costs are not particularly efficient to reduce benefit frauds or hamper profits. This suggests that the "cost problem" is not the rational ground for policy, but an ad hoc construction that serves the purpose of justifying general cutbacks striking at all personal assistance users.

Niklas Altermark, fil.dr, Statsvetenskapliga institutionen, Lunds universitet

Kontakt: niklas.altermark@svet.lu.se 


\section{En ny assistanspolitik}

Sedan den socialdemokratiska regeringens tillträde 2014 har de funktionshinderpolitiska besluten handlat om hur kostnaderna för den personliga assistansen kan dämpas. En statlig utredning har fått i uppdrag att ta fram förslag på besparingar, regeringen har fryst och sedan sänkt ökningen av schablonbeloppet för varje beviljad assistanstimme. I 2016 års regleringsbrev till Försäkringskassan (Socialdepartementet, 2015) ges myndigheten i uppdrag att bryta kostnadsutvecklingen inom assistansen. Sedan lagen om stöd och service för vissa funktionshindrade (LSS) infördes 1994, har utgångspunkten för funktionshinderpolitiska insatser varit att behoven ska styra kostnaderna. $\mathrm{Nu}$ har regeringen i stället fattat en rad beslut som innebär att kostnaderna ska minska utan hänsyn till om och hur dessa behov förändras. Dessutom har en rad förändrade lagtolkningar, som trädde i kraft 2006-2009, resulterat i att personer förlorat sin assistans och att inflödet av nya assistansanvändare dämpats (Näsman, 2016, s. 6).

Inom funktionshinderrörelsen beskrivs läget i dag som krisartat och den rådande politiska linjen som en utarmning av assistansreformen och dess intentioner. Under sommaren och den tidiga hösten 2016 börjar massmedia uppmärksamma konsekvenserna: hur personer med uppenbara behov av stöd och service får sin assistans indragen och hur detta drabbar assistansanvändare och anhöriga. Flera föräldrar till barn med funktionshinder ges plats i den offentliga debatten för att berätta om hur deras liv har försvårats. Samtidigt framhärdar regering och statliga myndigheter i att kostnadsutvecklingen inom assistansen är utom kontroll och måste brytas, att det finns ett omfattande "överutnyttjande" av assistansersättningen och att privata assistansanordnares vinstintresse driver upp kostnaderna (Begler \& Lender, 2016; Regnér, 2016d; Inspektionen för socialförsäkringen, 2015). Det funktionshinderpolitiska fokus som sedan införandet av LSS 1994 framför allt har kretsat kring lika rättigheter och inkludering, har därmed förskjutits till att handla om kostnader och besparingar.

Besparingspolitik som drabbar funktionshindrade är inte ett isolerat svenskt fenomen, utan spänner över stora delar av Västeuropa. Inte minst i Storbritannien pågår en politisk kamp mot utarmningen av samhällets stödsystem (se DPAC, 2014; Goodley, Lawthom \& Runswick-Cole, 2014). Inte heller är denna diskussion ny i en svensk kontext; redan 1995, alltså ett år efter assistansreformen, tillsatte regeringen en utredning med uppdraget att bryta kostnadsutvecklingen inom assistansen, och det genomfördes under LSS första tio år en rad förändringar med detta syfte. Det som är nytt med dagens situation är att assistansens kostnader har blivit den helt dominerande funktionshinderpolitiska frågan. Den diskuteras på ledarsidor och i debattprogram, och det är mot nedskärningar inom assistansen som funktionshinderrörelsen mobiliserar. I den utsträckning funktionshinderpolitik alls diskuteras i den allmänpolitiska debatten, handlar det alltså nästan uteslutande om hur pengar kan sparas inom assistansen. 
Min avsikt i den här artikeln är att visa hur den här politiken har gjorts möjlig genom att personlig assistans har konstruerats som ett "kostnadsproblem". Genom att analysera hur kostnadsökningarna inom assistansen problematiseras av regering, och i viss utsträckning av statliga myndigheter, blir det möjligt att förstå varför vi i dag har en helt annan funktionshinderpolitisk diskussion än för tio år sedan, hur besparingsåtgärderna framställs som legitima samt hur socialpolitisk åtstramningspolitik, mer generellt, motiveras. Syftet i den här artikeln är med andra ord inte att analysera vilken substans som finns i beskrivningarna av "kostnadsproblemet", förekomsten av fusk och privata anordnare som låter vinstkrav gå före kvalitet, utan hur föreställningen om "kostnadsproblemet" konstrueras och mobiliseras för att legitimera besparingspolitik.

Jag vill börja med ett exempel som åskådliggör det argument som jag kommer att driva: Åsa Regnér (S), ansvarig minister för LSS, utfrågas under Almedalsveckan 2016 av Hanna Kauppi från Arbetsgivarorganisationen KFO. På frågor som berör besparingarna inom den personliga assistansen återkommer ministern gång på gång till två olika standardsvar: (1) att "pengar inte går till det som det var tänkt" samt att (2) "förtroendet för LSS undergrävs om vi inte vet vart varje krona går". De här svaren är intressanta. Som jag genomgående kommer att visa har "förtroendekrisen" i standardsvar 2 i stor utsträckning skapats just genom politiska ifrågasättanden av den typ som exemplifieras av ministerns första standardsvar. Genom att i sin retorik gång på gång påpeka att kostnaderna ökar och genom att förklara dessa ökningar med "överutnyttjande", fusk eller oskäliga vinster, så bidrar ministern aktivt till att skapa den "förtroendekris" som hon använder för att legitimera besparingsåtgärder. Den här ögonblicksbilden från samtalet mellan Kauppi och Regnér illustrerar en mer generell struktur för hur åtstramningspolitiken rättfärdigas: genom att konstruera ett "kostnadsproblem" som antas undergräva assistansens legitimitet kan besparingspolitiken motiveras. En central aspekt av besparingspolitiken handlar alltså om att kommunicera en bild av att personlig assistans läcker pengar, vilket påstås bero på fusk och vinsthungriga assistansanordnare. Samtidigt visar min analys att de besparingspolitiska åtgärderna som genomförs inte är speciellt effektiva för att komma till rätta med vare sig fusk eller oskäliga vinstuttag. I stället för att förstå besparingspolitiken som en lösning på kostnadsproblemet, menar jag att "kostnadsproblemet" konstrueras för att legitimera en generell åtstramningspolitik (se Johnson, 2010, för en intressant parallell med sjukförsäkringen).

Innan jag utvecklar de här argumenten presenterar jag mina teoretiska utgångspunkter (under nästa rubrik) samt mitt materialurval (i resten av detta stycke). Analysen bygger på offentliga uttalanden och policydokument från den socialdemokratiska regeringen samt relevanta statliga myndigheter, från regeringsskiftet 2014 fram till den tidiga hösten 2016. Huvuddelen av materialet är från andra halvan 
av 2015 och framåt, vilket är den tidsperiod då regeringen aktivt har opinionsbildat $i$ assistansfrågan. Totalt består textmaterialet av ett tjugotal debattartiklar, fyra rapporter från statliga myndigheter som ofta åberopas i regeringens retorik, utredningsdirektiven för den nyligen tillsatta LSS-utredningen samt regleringsbreven för de myndigheter som har ansvar för eller tillsyn över den personliga assistansen. Jag har också gått igenom den sittande regeringens samtliga pressmeddelanden inom det funktionshinderpolitiska området. Eftersom jag i huvudsak är intresserad av hur politik underbyggs med hjälp av problembeskrivningar, ligger tonvikten i analysen på regeringens opinionsbildande arbete. Jag är intresserad av hur besparingspolitiken framställs som rimlig, varför regeringen argumenterar att besparingar är nödvändiga och vilka problem dessa påstås vara lösningar på. Därmed kan min undersökning beskrivas som en kritisk textanalys av hur socialpolitiska besparingar rättfärdigas.

\section{Problemskapande och målgruppskonstruktioner}

Jag presenterar under denna rubrik mina två huvudsakliga teoretiska inspirationskällor: Carol Bacchis (2009) analys av politik som problemskapande och Ingram och Schneiders (Schneider \& Ingram, 1993; Ingram, Schneider \& DeLeon, 2007) modell av hur policy legitimeras genom konstruktioner av politiska målgrupper. Båda dessa teorier frångår en traditionell syn på hur politik blir till; i stället för ett synsätt som ser politiska åtgärder som mer eller mindre rationella svar på givna problem, betonar såväl Bacchi som Ingram och Schneider hur problembeskrivningar och föreställningar om vissa "problematiska" grupper är konstruerade för att legitimera politiska åtgärder. Politik handlar med andra ord inte bara om problemlösande, utan också om problemskapande.

Som jag redan antytt, beskrivs den nuvarande assistanspolitiken som att ett antal politiska åtgärder (frysning av schablonbelopp, regleringsbrev till Försäkringskassan etc.) har designats för att lösa ett antal problem (stigande kostnader till följd av fusk, överutnyttjande och övervinster). Det är denna kedja av problem och politisk reaktion som jag kommer att ifrågasätta i den här artikeln. Detta förutsätter emellertid att vi måste röra oss bort från en traditionell syn på hur politik skapas. Utifrån en sådan, instrumentell, förståelse av hur politik blir till är policyprocessen uppdelad i ett antal faser där att identifiera problemet kommer först och att implementera politiska åtgärder kommer sist. Det här sättet att analysera policyprocesser har kritiserats för att vara idealtypiskt och förbise den politiska processens komplexitet (se Hill \& Hupe, 2002; Hajer \& Wagenaar, 2003, s. 5-7), men också för att det tenderar att betrakta politiska problem som separerade från det politiska problemlösandet (Bacchi, 2009). Som en konsekvens riskerar vi därmed att förbise hur beskrivningar av vad som utgör problem som politiken måste lösa i sig är uttryck för maktutövning. 
Från det här perspektivet är det med andra ord inte på förhand givet att kostnadsökningarna inom den personliga assistansen ska vara det centrala funktionshinderpolitiska problemet. När just denna fråga ändå sätts högst på den politiska dagordningen, innebär det samtidigt att andra tänkbara problemformuleringar negligeras.

Den här typen av problemskapande är en integrerad del av hur politik blir till; redan när ett samhällsfenomen uppmärksammas som "problematiskt", och därför kräver åtgärder, så har den politiska processen påbörjats (se Bacchi, 2009). Grundtanken med den här analytiska ingången är alltså att "politiska problem" inte är neutrala och självklara, utan socialt konstruerade och politiska. Det blir därför viktigt att granska de antaganden som olika problemformuleringar bygger på (Bacchi, 2009, s. 39-44). Det här sättet att närma sig politik som en problemskapande aktivitet har bland annat utvecklats av Bacchi (2009, s. 1-7, 25-32). Kärnan i hennes analys är att problem aldrig uppstår oberoende av makt och ideologi. För att ge ett exempel: när funktionshinderpolitiken växte fram som ett separat politikområde, under slutet av 1800-talet och början av 1900-talet, så var det mot bakgrund av insikten att det fanns grupper i samhället som inte kunde arbeta, som inte såg ut eller betedde sig som "normala" människor och som staten därmed var tvungen att göra någonting åt (se Altermark, 2016). På det här sättet växte institutioner för personer med intellektuella funktionshinder fram som ett svar på att opinionsbildare, psykiatriker och politiker gemensamt frammanade en problembild där vissa människors normavvikande beteenden kopplades till kriminalitet, lösdriveri och ekonomiska kostnader (se Axelsson, 2007). Institutionsvården kom med andra ord inte till som ett svar på ett objektivt existerande "problem", utan för att den här gruppen definierades och började beskrivas som ett hot mot samhällsordningen som staten var tvungen att förhålla sig till (se Altermark, 2016). När vi på det här sättet betraktar framväxten av olika politiska lösningar i en historisk backspegel blir det tydligt att problembeskrivningar speglar de värderingar och maktordningar som råder i samhället (se Brown 1995; Foucault 1990). Detta gäller så klart också för vår samtid; även dagens politiska problem är inbäddade i normer och värderingar som får vissa fenomen att framstå som problematiska och som olika samhällsaktörer därför kan mobilisera för att legitimera politiska åtgärder. En fundamental aspekt av hur politik blir till handlar på det här sättet om att definiera vad som utgör problemen som politiken ska lösa.

På flera sätt löper Ingram och Schneiders (1993) teori om policyskapande och målgruppskonstruktioner parallellt med Bacchis. Även i deras analys är syftet att röra sig bort från en instrumentell och formell politikförståelse för att granska de underförstådda antaganden som politiken bygger på. Precis som hos Bacchi är dessutom hur vi pratar om, skildrar och tolkar fenomen centrala aspekter av hur politik blir till. I Ingram och Schneiders (1993; Ingram, Schneider \& DeLeon, 2007) fall handlar det om hur politikens målgrupper skapas, reproduceras och därigenom blir en del av hur 
politiska åtgärder legitimeras. Den grundläggande tanken i detta teoribygge är enkel: för att en välfärdsreform ska uppfattas som legitim måste den grupp som tjänar på reformen uppfattas som förtjänt av reformens vinster. Nedskärningar kommer att uppfattas som legitima om målgruppen uppfattas som oförtjänt av samhällets resurser. Ingram och Schneiders poäng är alltså att politiska reformprogram kommer att bedömas givet vilka målgruppskonstruktioner de mobiliserar. Detta öppnar så klart upp för att politiska beslutsfattare medvetet försöker förmedla en bild av att grupper får mer än vad de förtjänar (om det handlar om nedskärningar) eller är förtjänta av mer än de för tillfället får (om det handlar om förbättringar). Den här typen av målgruppskonstruktioner fungerar som en slags retoriska stödanordningar - när policyer beslutas om av politiker och när de implementeras av tjänstemän (Stubbergaard, 2010).

Som vi kommer att se i den empiriska analysen har den här typen av målgruppskonstruktioner en stor betydelse i hur nedskärningarna inom den personliga assistansen legitimeras; genom att måla upp bilden av att assistansen överutnyttjas kommuniceras en idé om att personer med funktionsnedsättningar får mer stöd än de har rätt till, samtidigt som de privata anordnarna beskrivs som oförtjänta profitörer på en generös assistansersättning. Dessa beskrivningar länkar in i den överordnade problembeskrivningen av skenande kostnader som samhället saknar kontroll över och fungerar därmed som ett verktyg för att rättfärdiga besparingspolitiken.

\section{Att skapa ett "kostnadsproblem"}

Den empiriska analysen som följer är uppdelad under två rubriker. Jag analyserar först den generella konstruktionen av "kostnadsproblemet", där jag tar fasta på fyra relaterade aspekter: (1) hur kostnadsproblemet innebär att alternativa problem ställs åt sidan; (2) hur kostnadsökningen inom LSS beskrivs som ett legitimitetsproblem och hur detta bygger på en föreställd "korrekt" kostnadsnivå; (3) hur problembeskrivningen av assistanskostnaderna ställer olika grupper av personer med funktionshinder mot varandra samt (4) hur skapandet av ett kostnadsproblem gör det möjligt att beskriva besparingspolitiska åtgärder som en politik för "ökad kontroll". Under nästa rubrik visar jag hur den här problembeskrivningen lutar sig mot specifika målgruppskonstruktioner av assistansanvändare och privata assistansanordnare.

För att förstå den nuvarande politiska linjen, måste vi alltså greppa hur "kostnadsutvecklingen" gjorts till det centrala funktionshinderpolitiska problemet. För detta är inte en självklar problembeskrivning. Till exempel har en lång rad offentliga utredningar fastställt att LSS målsättningar om jämlikhet och fullt medborgarskap inte har realiserats. Forskningen om funktionshinderpolitiken delar i mycket stor utsträckning denna bild, både i Sverige och internationellt (se Walmsley, 2005; Clement 
\& Bigby, 2010). Bortsett från att personer med funktionshinder tenderar att vara exkluderade på arbetsmarknaden, i civilsamhället och har sämre ekonomiska förutsättningar än resten av befolkningen (Socialstyrelsen, 2010), finns det också gott om undersökningar som belägger att LSS olika insatser inte fungerar givet lagstiftningens bakomliggande intentioner, vilket man kan tycka vore ett rimligare fokus för den funktionshinderpolitiska debatten (se Altermark, 2016, kap. 6; Bahner, 2016). Det är slående att de problem som återkommande har specificerats av både forskarsamhället och statliga myndigheter helt saknas i regeringens utredningsdirektiv för och kommunikation om funktionshinderpolitiken, till förmån för ett snävt kostnadsfokus på den personliga assistansen.

Med en tillspetsad formulering kan man därför säga att funktionshindrade personers levnadsvillkor framstår som betydligt mindre viktigt än vad dessa liv kostar. Det speglar i sig en värdering och föreställning med långa historiska rötter: genom 1900talet har samhällskostnaderna av funktionshinder varit ett återkommande tema i den politiska debatten, medan livskvaliteten för människor som tillhör gruppen endast har stått högt på den funktionshinderpolitiska dagordningen från 1970-talet och framåt (se Grunewald, 2008). Man kan därför säga att dagens kostnadsfokus reaktiverar en djupt rotad problemställning om personer med funktionshinder: "Hur ska vi ha råd med dem?" (Carlson, 2010; Goodey, 2011). I dagens kontext spelar dessutom nya välfärdspolitiska styrningsideal in. Det är ett välbelagt faktum att socialpolitiken, även internationellt, alltmer har kommit att fokusera på minskade offentliga åtaganden för att motverka "bidragsberoende" (se Fraser \& Gordon, 1997; Cruikshank, 1999) och att den styrningstrend som brukar benämnas "New Public Management" har gjort kostnadseffektivitet till ett överordnat kvalitetsmått för all offentlig verksamhet (se Pollitt \& Bouckaert, 2004; Lundquist, 1998). Den sammantagna bilden av den funktionshinderpolitiska agenda som regeringen har satt blir med andra ord att fokus på assistansens kostnader dominerar närmast totalt. I utredningsdirektiven för den nya LSS-utredningen nämns förvisso andra funktionshinderpolitiska förbättringsområden, men eventuella reformer ska samtidigt finansieras genom besparingar inom assistansen (Dir. 2016:40). I enlighet med Bacchis modell tränger kostnadsproblemet på det här sättet undan andra tänkbara problemformuleringar, som till exempel hade kunnat fokusera på hur samhällets stöd kan utvecklas eller som utgår från de ojämlikheter och exkluderingar som personer med funktionshinder alltjämt drabbas av.

Utgångspunkten för konstruktionen av kostnadsproblemet är att kostnaderna för den personliga assistansen har ökat i snabbare takt än antalet personer som beviljas personlig assistans (Försäkringskassan, 2016, s. 7-10), vilket alltså innebär att det genomsnittliga antalet beviljade timmar per person har ökat (11). Detta påpekas kontinuerligt i regeringens retorik. För att motivera den särställning som assistans- 
kostnaderna ges i den offentliga funktionshinderpolitiska diskursen beskrivs den här utvecklingen återkommande som en fråga om legitimitet. Ansvarig minister, Åsa Regnér (se Regnér, 2016a; Regnér \& Karlsson, 2016), har vid ett flertal tillfällen argumenterat att funktionshinderrörelsens oro över fokuseringen vid kostnader bygger på en falsk motsättning mellan människors rättigheter och vad den personliga assistansen kostar. I stället menar Regnér att regeringens kostnadsfokus är ett uttryck för ett försvar av dessa rättigheter, eftersom LSS och den personliga assistansen bara är legitima givet att vi vet att assistansens kostnader "gå[r]r till rätt saker" (se Andersson, 2015. I själva verket gynnas alltså assistansanvändare av mer kostnadskontroll (Regnér, 2016b). Liknande beskrivningar görs också av Försäkringskassan (2016, s. 5), som i en av sina rapporter till exempel hävdar att omfattningen av bedrägerier inom assistansen är "systemhotande" eftersom de antas leda till att assistansen förlorar sin legitimitet. Legitimitetsbegreppet fungerar här som ett sätt att upphäva konflikten mellan besparingar och värnande om funktionshindrades rättigheter; genom att hänvisa till en föreställd förtroendekris för assistansen kan besparingspolitiken motiveras som ett försvar av assistansen.

Det finns emellertid varken forskning eller statistik som tyder på att den personliga assistansen är speciellt ifrågasatt, varken bland medborgare eller i den offentliga debatten. Den mediala granskning som har handlat om personlig assistans har heller inte berört de generella kostnadsnivåerna för assistansen, utan har fokuserat på enskilda fall av ekonomisk brottslighet. En enkel sökning på opinionsartiklar som berör personlig assistans visar snarare att kostnadsfrågan börjar diskuteras först efter att regeringen har börjat opinionsbilda med fokus på kostnadsökningarna (även om det finns spridda fall av kritik även tidigare). På det här sättet kan knappast regeringens politik betraktas som ett svar på en förtroendekris för assistansen. Snarare förefaller det som att regeringens eget agerande har lyft upp assistanskostnaderna på den politiska dagordningen och därigenom initierat debatten om kostnaderna, för att i nästa led referera till ett legitimitetsunderskott som orsaken till att det behövs en besparingspolitik. På det här sättet kan man, utifrån Bacchi (2009), se regeringens och de statliga myndigheternas egna insinuationer och påståenden om fusk och överutnyttjande som ett sätt att skapa en legitimitetskris som motiverar den politik man vill föra.

Retoriken kring den påstådda legitimitetskrisen för assistansen bygger på antagandet att det finns en korrekt kostnadsnivå som kostnadsökningarna överstiger. Anledningen till att regeringen menar att det uppstår en förtroendekris är att kostnadsökningarna inte har godtagbara orsaker, att pengarna går till fel saker och att det saknas kunskap om vart de egentligen tar vägen. I sak kan detta så klart stämma - det är till exempel svårt att argumentera mot djupare kunskap om hur utbetald assistansersättning används. Poängen här handlar dock om hur de här argumenten 
mobiliseras för att legitimera politiska besparingsåtgärder. Jag menar att regeringen modellerar två relaterade problem. Å ena sidan saknas det kunskap om vad kostnadsökningarna beror på, vilket alltså skapar ett behov av kartläggningar och utredning. $\AA$ andra sidan antas samtidigt att kostnadsökningarna inte har legitima förklaringar, vilket motiverar de besparingsåtgärder som redan genomförts. I den strida strömmen av debattartiklar från Socialdepartementet (se Regnér, 2015b; 2016a; 2016b; 2016c; 2016d) är en återkommande retorisk figur att "människor ska få det stöd de har rätt till". Vilket samtidigt implicerar att det i dagsläget beviljas en stor mängd assistanstimmar som assistansanvändare inte har rätt till - annars skulle det ju inte vara möjligt att dämpa kostnaderna. Detta gör det i sin tur möjligt att använda sig av en terminologi som fastslår att det finns ett "överanvändande" och "överutnyttjande" av personlig assistans (vilket jag återkommer till under nästa rubrik). På det här sättet lutar sig regeringens retorik mot en föreställd distinktion mellan korrekt och orättfärdig assistans, där man samtidigt försäkrar att nedskärningarna bara kommer att gälla den senare kategorin (se Försäkringskassan, 2016, s. 27). Att de politiska besluten vi hitintills har sett innebär generella nedskärningar som drabbar alla assistansanvändare avspeglas alltså inte i regeringens problemformulering och argumentation, som snarare bygger på att bara de som inte har rent mjöl i påsen kommer att drabbas.

En annan aspekt av problemskapandet som omgärdar assistansen har att göra med hur personlig assistans ställs mot andra insatser. Rent faktiskt slår kommittédirektiven för LSS-utredningen som sagt fast att reformer inom andra områden av LSS ska finansieras med besparingar inom assistansen (Dir. 2016:40). Samtidigt finns det ett flertal exempel på hur assistanskostnaderna i regeringens retorik länkas samman med att andra grupper av personer med funktionshinder får för lite stöd. I den ovan refererade utfrågningen i Almedalen tog till exempel ministern upp att det finns personer som har rätt till ledsagning som inte får denna insats - detta i en diskussion om kostnadsökningarna inom assistansen. Samma koppling görs i en rad debattartiklar (Regnér, 2015a; 2016c; 2016d). Tillsammans med utredningsdirektiven skapar detta intrycket att det finns ett orsaksförhållande, till exempel just mellan beviljad ledsagning och assistansens kostnader. I sak är dessa påståenden enkla att ifrågasätta. Att ökningen av den statliga assistansen skulle ha ett direkt samband med hur många som beviljas ledsagning enligt LSS - trots olika huvudmän och separat budgetering - är i princip samma sak som att hävda att kommunala fritidsgårdar får stänga när de statliga muséerna slopar sina avgifter. Syftet här är dock inte att förstå hur bra regeringens problematisering fungerar som verklighetsbeskrivning, utan som legitimeringsgrund för besparingar. Kopplingen mellan assistansens kostnader och övriga LSS-insatser skapas i samma ögonblick som det görs klart att besparingar inom personlig assistans ska resultera i satsningar på andra LSS-insatser. Sambandet finns för att regeringen bestämmer att det ska finnas. I förlängningen innebär detta att regeringen konstruerar 
en motsättning mellan olika grupper av funktionshindrades intressen: assistansanvändare har ett intresse av bibehållet stöd, medan personer med andra insatser har ett intresse av satsningar som möjliggörs av besparingar inom assistansen. Detta är med andra ord en metod för att ställa olika grupper av personer med funktionshinder mot varandra.

Slutligen är det viktigt att lägga märke till hur besparingspolitiken etiketteras. Situationen inom den personliga assistansen beskrivs genomgående som att det saknas kontroll över kostnadsutvecklingen, att vi inte vet vart pengarna tar vägen, men att de i alla fall inte verkar gå till rätt saker. Kostnadsökningarna blir en abstraktion som frammanar bilden av en situation bortom sans. I sin kommunikation kring assistansen understryker också regeringen kontinuerligt att de politiska åtgärderna syftar till att säkerställa att pengarna hamnar på rätt plats. Trots att det alltså är generella nedskärningar, snarare än tillspetsad tillsyn och bättre handläggning, som implementeras. Lägesbeskrivningen av situationen gör det samtidigt möjligt att saluföra de besparingspolitiska åtgärderna på ett mer tilltalande sätt; det handlar inte om åtstramningar, utan är en politik för "ökad kontroll". I den retorik som regeringen använder för att beskriva sin politik är just ordet "kontroll" frekvent och helt centralt (se Regnér 2016a; 2016b; 2016d). Till exempel poängterar ansvarig minister i ett antal olika debattartiklar att det inte finns någon motsättning mellan "kvalitet" och "kontroll". I sak är detta så klart en truism, eftersom hela tanken med kontroll är att garantera kvalitet. Den analytiska poängen här handlar om att genom etiketteringen av besparingsåtgärder som "kontroll" försöker man upphäva motsättningen mellan att värna den personliga assistansen och att dra ner på dess kostnader. Att den förda politiken de facto innebär sänkta ersättningsnivåer per beviljad assistanstimme för alla assistansanvändare samt att färre timmar (allt annat lika) beviljas, skyms i en diskurs som betonar kvalitetssäkring och ökad kunskap.

\section{"Överanvändare" och "vinstmaximerare"}

Jag argumenterade ovan för att en central aspekt av hur "kostnadsproblemet" utformas är att man lutar sig mot antagandet att det finns en "korrekt" nivå för assistansens kostnader, men utan att denna nivå specificeras. Samtidigt finns det som sagt ett underskott av kunskap om vad kostnadsökningarna beror på. Faktum är att detta kunskapsglapp om kostnadsökningarna i sig fyller en viktig diskursiv funktion, eftersom det lämnar utrymme för regering och myndigheter att lansera egna förklaringar. Detta illustreras tydligt i en debattartikel signerad av Försäkringskassans generaldirektör och dess (tillförordnade) försäkringsdirektör (Begler \& Lender, 2016). Kostnadsproblemet är den självklara utgångspunkten för artikeln, där ökningen av antalet assistanstimmar används för att vederlägga bilden att det skulle råda "kris" 
inom den personliga assistansen. Den första tredjedelen av artikeln ägnas just åt att specificera hur stor del av kostnadsökningarna regering och myndigheter förstår orsakerna bakom och hur stor del som inte kan förklaras. Att vi inte vet "vart varje krona går" - för att parafrasera ansvarig minister - lämnar i sin tur utrymme för Begler och Lender att lansera sin egen förklaring, just i form av "överanvändning"/fusk och privata vinstintressen. Det ska noteras att de inte har empiriska fakta för att göra denna koppling. Givet hur deras text är strukturerad, framstår dock deras förklaring som det enda rimliga svaret på kunskapsluckan om varför utgifterna för assistansen skenar. Begler och Lender bortser här helt från den omfattande kritik som har funnits mot de dominerande uppskattningarna av fusket inom assistansen, och de ignorerar den statistik om vinsterna inom assistansbranschen som branschen själv har tagit fram. På det här sättet möjliggör det osäkra kunskapsläget förklaringsmodeller som fungerar som en legitimitetsgrund för besparingspolitiken. Jag tittar härunder närmare på hur de här förklaringsmodellerna lutar sig mot målgruppskonstruktioner av assistansanvändare som "överanvändare" och privata assistansanordnare som "vinstmaximerare". Målgruppskonstruktionerna förstärker i sin tur de antaganden som ligger till grund för besparingspolitiken, då assistansanvändare framstår som oförtjänta behövande som "överutnyttjar" systemet och assistansföretag som oförtjänta rika vars vinstintresse driver upp kostnadsökningarna.

Som jag redogjorde för i min teoretiska introduktion har Ingram och Schneider (1993; Ingram, Schneider \& DeLeon, 2007) argumenterat för att välfärdspolitik ofta motiveras av speciella målgruppskonstruktioner, som i min analys förstås som att de understödjer skapandet av "kostnadsproblemet". Jag börjar med att titta på hur diskursen om "fusk" och "överanvändning" figurerar på det här sättet. Det ska direkt sägas att det så klart förekommer direkt fusk, där personer medvetet överdriver eller simulerar stödbehov för att sko sig själva eller där assistansanordnare blåser upp behoven. Till exempel har det projekt som Försäkringskassan drivit tillsammans med andra myndigheter, under namnet "Operation Fjord", lett till att ett antal bedragare har kunnat åtalas och fällas samt att ett antal oseriösa assistansanordnare har fått avveckla sin verksamhet (se Försäkringskassan, 2016). Det intressanta här är emellertid inte de fakta vi har om fusket eller hur det kan stoppas, utan hur föreställningen om fusk mobiliseras för att motivera de politiska besparingsåtgärder vi sett under de senaste åren. Som Björn Johnson (2010) har visat när det gäller sjukförsäkringen (som visserligen skiljer sig från assistansen i att den är betydligt mindre komplex) tenderar uppskattningar av fusk att överdrivas för att motivera politiska åtstramningar. Det ligger dessutom i sakens natur att det är mycket svårt att uppskatta i vilken utsträckning olika bidragssystem utnyttjas på det här sättet. När det gäller assistansen, anges ofta att fusk och överanvändning uppgår till cirka 10 procent av alla utbetalningar (Försäkringskassan, 2016, s.19). Denna siffra har emellertid blivit kraftigt ifrågasatt 
på metodologiska grunder, då siffran bygger på expertuppskattningar snarare än reella empiriska data (se Näsman, 2016; Altermark \& Nilsson, 2017). Metoden för att ta fram dessa uppskattningar har aldrig tidigare använts för att generera bedömningar av mörkertal, eller ens besvara samhällsvetenskapliga frågeställningar över huvud taget, och har dessutom tillämpats på sätt som radikalt avviker från hur metoden är tänkt att användas (Altermark \& Nilsson, 2017). Emellertid är inte bristen på kunskap nödvändigtvis ett problem om syftet är att motivera besparingsåtgärder; osäkerheten kring omfattningen gör att Försäkringskassan och regeringen kan lansera uppskattningar som väcker uppmärksamhet och kallar till politisk handling. Det är också genomgående i kommunikationen som omgärdar assistansen att man hänvisar till ett antaget stort mörkertal. I den debattartikel som signerats av Försäkringskassans generaldirektör och försäkringsdirektör illustreras mörkertalet med metaforen att vi inte tar det relativa fåtal personer som åker fast för fortkörning som intäkt för att det är ett marginalfenomen (Begler \& Lender, 2016). Läsaren leds att tro att vi på motsvarande sätt bara ser toppen av ett isberg när det kommer till dem som blir fällda för bedrägerier inom assistansen. Genom att luta sig mot antagandet om "det stora mörkertalet" blir det därmed möjligt att argumentera för att kostnadsökningarna är oskäliga och beror på fusk, utan att det finns ett faktiskt empiriskt underlag för de här påståendena. Faktum är att vi sedan 2008 har sett återkommande referenser till fusk och överutnyttjande, vilket redan motiverat hårdare kontroll av personer som får personlig assistans (se Näsman, 2016, s. 64).

I termer av målgruppskonstruktioner etablerar den här diskursen idén att assistansanvändare, som kollektiv, får mer assistans än de har laglig rätt till. Samtidigt som både regeringen och Försäkringskassan poängterar att de flesta assistansanvändare inte skor sig på systemet, får de återkommande referenserna till fusk och "överutnyttjande" effekten att det framstår som en helt central förklaring till varför assistanskostnaderna ökar. Misstänkliggörandet drabbar därmed assistansanvändare som grupp, även om inte alla beskrivs som skyldiga. Det är en förskjutning av hur personer som får personlig assistans porträtteras: vid LSS-införandet beskrevs personer med funktionshinder genomgående som förtjänta behövande, de framställdes som exkluderade och utsatta för orättvisor, vilket i sin tur motiverade en politik som skulle tillåta dem att bli bidragande samhällsmedlemmar (se t.ex. SOU 1992:52). En genomlysning av regeringens och myndigheternas beskrivningar av gruppen i dag visar att bilden av en diskriminerad och orättvist behandlad grupp i stor utsträckning har ersatts av beskrivningar av ett kollektiv som "överutnyttjar"/"överanvänder" (Socialdepartementet, 2015; Begler \& Lender, 2016).

Den oprecisa begreppsapparaten är helt central för hur de här argumenten konstrueras. "Överanvändningens"/"överutnyttjandets" funktion är att fungera som benämning på det som Ingram och Schneider kallar för "oförtjänt behövande", men 
som ändå inte innebär att man medvetet och planerat skor sig på systemet. Även om det inte direkt fuskas, så får assistansanvändare mer än de har rätt till. Som jag påpekade ovan blir begreppen enbart meningsfulla i relation till en tänkt korrekt nivå, som samtidigt inte preciseras. Det enda vi egentligen kan säga om vad "överanvändande" betyder, utifrån det empiriska materialet, är att det antas ligga bakom en stor del av kostnadsökningarna. Vi ställs därmed inför ett cirkelresonemang:Varför ökar kostnaderna? För att det finns ett överanvändande. Hur vet vi att det är ett överanvändande? För att kostnaderna ökar. Varför måste kostnadsökningarna dämpas? För att de beror på överanvändning. Hur vet vi att de beror på överanvändning? För att kostnaderna ökar. Och så vidare.

Snarare än ett empiriskt faktum menar jag därför att "överanvändning" är en diskursiv figur som används för att legitimera nedskärningar genom att misstänkliggöra assistansens målgrupp. Att använda begreppet blir ett verktyg för att slå fast både vad kostnadsökningarna beror på ("överanvändning") och att de inte är rättfärdigade (dock utan att en motiverad nivå specificeras). På det här sättet är begreppet substanslöst; det består endast av bedömningen att assistansanvändare får för mycket assistans, samtidigt som det fungerar som ett redskap för att ifrågasätta assistansanvändare (och som vi kommer att se nedan, assistansanordnare) som antas driva upp antalet beviljade timmar.

Den andra målgruppskonstruktionen av betydelse för hur assistansen problematiseras finner vi i beskrivningarna av de privata assistansanordnarna. Precis som fusket och överanvändningen lanseras privata vinstintressen som en förklaring till ökade kostnader. Grundargumentet summeras i en rapport från Inspektionen för socialförsäkringen (2015, s. 87-89): privata anordnare har incitament att överdriva den enskildes stödbehov då detta ger större vinster. Detta är så klart svårt att argumentera mot i sak. Argumentet blir i sin tur framträdande då regeringen lanserar den nya LSS-utredningen, vilket illustreras av nedanstående citat ur en debattartikel i Dagens Samhälle:

\footnotetext{
Utredningen om assistansersättningens kostnader som gjordes under förra mandatperioden konstaterade att schablonersättningen gav starka ekonomiska drivkrafter för alla aktörer att försöka öka antalet beviljade timmar, eftersom varje timme gav en högre vinst. Utredningen konstaterade också att det finns en risk för att dessa företag överdriver assistansbehoven, eftersom företagen har ett starkt ekonomiskt intresse av att få många timmar assistansersättning i sin verksamhet. (Regnér, 2016c)
}

När det gäller de privata och vinstdrivande assistansanordnarna är det i sig inte ett orimligt argument. I regeringens argumentation länkas det dock till det faktum att många privata anordnare anlitar jurister som hjälper assistansanvändaren i handlägg- 
nings- och ansökningsfasen, vilket enligt regeringen alltså innebär "att pengarna inte går till rätt saker".

Återigen: det här är så klart bara problematiskt givet grundantagandet att fler timmar i sig själv är dåligt, det vill säga att privata anordnare skapar ett stödbehov som egentligen inte finns eller att de handlar på sätt som står i motsättning till assistansanvändarens bästa. För om juristerna hjälper den enskilde att få de timmar hen har rätt till, utifrån lagstiftningens intentioner, så är ju snarare systemfelet att juridisk rådgivning är nödvändigt för att rätt assistans ska beviljas. Det är sant att assistansanvändare med privata anordnare i genomsnitt har fler assistanstimmar och det är inte alls omöjligt att detta i någon utsträckning beror på sagda juridiska rådgivning. Det stämmer också att assistansmarknaden i dag i högre utsträckning domineras av privata anordnare (Inspektionen för socialförsäkringen, 2015). Däremot finns det ingenting som säger att det innebär att privata anordnare bidrar till att assistanstimmar beviljas som saknar lagstöd. Det kan ju också vara så att assistansanvändare som väljer kommunal assistans beviljas för få timmar och att den juridiska expertisen som ges via de privata anordnarna behövs för att de ska få det stöd som krävs för att de utifrån lagstiftningens formulering - ska kunna "leva som andra" (5 § LSS). Utifrån andra antaganden om vad som är en skälig nivå för assistansen hade det lika gärna gått att komma fram till att det finns ett problem med "underanvändning". Återigen förutsätter regeringens retorik att ökningar i sig är dåliga och överstiger en föreställd korrekt nivå, trots att den personliga assistansens målgrupp knappast har blivit de fullt inkluderade medborgare som lagstiftningen postulerar (Socialstyrelsen, 2010).

I Inspektionen för socialförsäkringens rapport, som refereras ovan, framställs inte bara företagens incitament som en orsak bakom ökade kostnader, utan även assistansanvändarens (Inspektionen för socialförsäkringen, 2015, s. 5). Påståendet är intressant, eftersom det belyser ett faktum som egentligen inte är så överraskande: assistansanvändare vill ofta ha mer assistans. Det innebär också att assistansanvändarens och assistansanordnarens intressen här inte nödvändigtvis står i motsättning till varandra, det vill säga företagens ansträngningar att öka antalet beviljade timmar kan ju faktiskt gagna personer med funktionshinder. I en rapport publicerad av Försäkringskassan (2016, s. 26) finns en liknande beskrivning av incitamentsstrukturen för assistansanvändare och anordnare:

Det ska betonas att denna strävan från både mottagare och anordnare att erhålla fler assistanstimmar är fullt förståelig - det ligger helt enkelt i deras gemensamma intresse. Samtidigt är det klart att dessa drivkrafter utövar en press uppåt på det antal timmar assistansersättning som beviljas och så kommer det sannolikt att vara så länge nyttan och intäkten av en extra timme assistans överstiger marginalkostnaden, det vill säga kostnaden för att erhålla och tillhandahålla ytterligare en timme assistans. 
Det reser återigen frågan vad det är som är så problematiskt med att kostnaderna ökar. Om assistansanvändare har ett intresse av fler beviljade timmar, är inte det ett tecken på att för få timmar beviljas? Det som Försäkringskassan här benämner som "en press uppåt" ska kanske snarare förstås som att assistansanvändare vill få assistans så att de kan leva sina liv utifrån samma villkor som människor utan funktionshinder - vilket alltså är precis vad lagstiftningen formulerar som sin övergripande målsättning. Samtidigt är det påfallande att assistansanvändarens incitament oftast faller bort i regeringens hänvisningar till dessa rapporter - i stället blir det endast de privata anordnarnas vinstintressen som beskrivs som en orsak till kostnadsökningarna.

Det finns så klart en generell och viktig debatt att föra om vinstuttag i välfärdsverksamheter - en debatt där jag själv är starkt kritisk till att skattepengar ska gå till vinstutbetalningar. Det ska också sägas att det förekommit uppgifter i media om privata anordnare som definitivt reser frågor om spänningar mellan assistansanvändares intressen och vissa privata anordnares vinstintressen. Poängen med regeringens retorik är dock inte att föra en sådan ideologisk driven diskussion, utan att lansera en målgruppsbild som gör att besparingar framstår som mer legitima. Det understryks av faktumet att de politiska åtgärderna knappast är designade för att specifikt komma åt de assistansanordnare som tar ut störst vinster. Snarare är det de stora anordnarna, som kan göra stordriftsfördelar och har sparat ihop ett kapital, som har bäst förutsättningar att klara av besparingarna. Det är företagen med minst vinstmarginaler som kommer att slås ut först. Syftet med den förda politiken är inte att lösa problemet med övervinster, i så fall hade tak för vinstuttag eller krav på återinvesteringar i verksamheten varit mycket mer effektiva åtgärder än generella nedskärningar. Snarare är retoriken om "övervinster" en del av en målgruppskonstruktion som legitimerar besparingspolitiken, även om besparingspolitiken knappast kommer åt övervinsterna.

Den sammantagna bilden blir alltså att problematiseringen av kostnadsökningen lutar sig mot två målgruppskonstruktioner: "överanvändaren"/"fuskaren" och "vinstmaximeraren". De här målgruppskonstruktionerna används i sin tur för att fylla kunskapsglappet om vad kostnadsökningarna inom assistansen beror på, på ett sätt som framställer det som att besparingspolitiken drabbar grupper som inte är förtjänta av en generös assistansersättning.

\section{Är motstånd möjligt?}

Den sammantagna bilden är att vi har en situation där assistansen beskrivs som ett kostnadsproblem, vilket tjänar syftet att legitimera en generell besparingspolitik. Samtidigt har regeringens besparingsåtgärder i själva verket mycket lite att göra med den problembeskrivning som legitimerar politiken. Om problemet verkligen hade 
varit att pengarna "går till fel saker", eller att "vi inte vet vart varje krona tar vägen", så hade lösningen knappast varit att ge färre kronor till alla assistansanvändare, utan att undersöka och beivra de fall där pengarna hamnar på villovägar. På motsvarande sätt är frysningar och sänkningar av schablonbeloppet för varje assistanstimme inte ett effektivt sätt att komma till rätta med "övervinster" och "överutnyttjande". Politiska åtgärder som verkligen designats för att komma till rätta med vinstuttag och fusk hade behövt vara betydligt mer precisa. Mot bakgrund av den problembeskrivning regeringen gör, silar besparingspolitiken mygg och sväljer kameler; man genomför generella nedskärningar genom att ge Försäkringskassan i uppdrag att spara pengar och genom att minska uppräkningen av schablonbeloppet, men riktar inga specifika åtgärder mot vare sig "överutnyttjande", direkt fusk eller övervinster. Mitt argument är emellertid inte att "kostnadsproblemet" används som utgångspunkt för att designa effektiva åtgärder, utan har konstruerats för att legitimera en generell besparingspolitik. Regeringens och myndigheternas beskrivning av kostnadsproblemet inom assistansen är alltså inte den förda politikens rationella grundförutsättning, utan en problematisering som syftar till att rättfärdiga, snarare än att utforma, besparingar. "Kostnadsproblemet", så som det beskrivs, kan inte lösas av de besparingspolitiska åtgärderna. Däremot kan "kostnadsproblemet" göra så att dessa åtgärder framstår som rimliga.

De argument som jag drivit i den här artikeln har implikationer för hur vi ska betrakta möjligheterna att göra motstånd mot besparingspolitiken. För det första antyder analysen att det är viktigt att inte bekräfta regeringens beskrivning av "kostnadsproblemet". Den politiska filosofen Wendy Brown (1995) har varnat för att formulera kritik inom ramarna för den rådande maktregimens problembilder. I det aktuella fallet kan detta fungera som en varning mot att ta "kostnadsproblemet" för givet. Det är sant att det finns många goda argument för att kostnaderna för assistansen överdrivs och att det finns dolda alternativkostnader som regeringen inte beaktar. Ett alltför starkt fokus på det här riskerar dock att leda till den beklagliga konsekvensen att den funktionshinderpolitiska debatten låses fast i en ekonomisk diskurs som alltjämt handlar om kostnader, snarare än levnadsvillkoren för personer med funktionshinder. Den helt centrala normkällan för svensk funktionshinderpolitik har under de senaste decennierna varit $\mathrm{FN}$ :s deklaration om mänskliga rättigheter: anledningen till att vi har assistans är, enligt lagstiftningen, inte att den ska generera samhällsekonomiska vinster, eller att insatserna ska vara ekonomiskt effektiva, utan att personer med funktionshinder har en okränkbar rätt att leva som fullvärdiga medborgare (Prop. 1992/93:159; Prop. 1999/00:79).

Vi har i dag en situation där det inte finns någon politisk debatt om hur samhällets stöd till personer med funktionshinder kan förbättras, hur vi ska komma längre i ambitionen att nå jämlikt och fullt medborgarskap eller hur maktrelationerna mellan 
personer med funktionshinder och samhället i övrigt ska jämnas ut. Ett ensidigt kostnadsfokus sväljer allt utrymme för en sådan, progressiv och framåtblickande, diskussion. Tiden efter LSS har präglats av att delar av funktionshinderrörelsen ofta har varit relativt tätt knuten till staten, som deltagare i utredningar och som dialogpartner. Givet att vi nu har en funktionshinderpolitisk debatt som utgår från en problembild som få företrädare för rörelsen delar, är det inte troligt att enbart spela rollen som dialogpartner är det mest effektiva; så länge vi är fångade i ett snävt kostnadsfokus spelar det mindre roll huruvida regering och myndigheter har för avsikt att lyssna på rörelsen - problemet är ju redan definierat. Det visar på att ett motstånd mot nedskärningspolitiken inte bara kan utgå från att besvara regeringens och de statliga myndigheternas argument om "kostnadsproblemet", utan måste också försöka etablera andra problembilder, som tar sin utgångspunkt i levnadsvillkoren för personer med funktionshinder. Det är inte sannolikt att LSS-utredningen kommer att producera förslag som gagnar funktionshindrades långsiktiga intressen och värderingar och det är inte sannolikt att regeringen kommer att föra en politik som stärker assistansen eller LSS. En sådan politik förutsätter nämligen att vi först etablerar andra sätt att tänka kring vilka de funktionshinderpolitiska problemen egentligen är. 


\section{Referenser}

Altermark, N. (2016) After inclusion. Intellectual disability as biopolitics (Lund Political Studies 180). Lund: Lunds universitet.

Altermark, N. \& Nilsson, H. (2017) "Det handlar om miljarder". En metodanalys av hur assistansfusket bedöms av svenska myndigheter (STIL:s rapportserie 13).

Andersson, M. (2015) Vi måste se över systemet för LSS. Aftonbladet, den 18 december 2015. [http://www.regeringen.se/debattartiklar/2015/12/vi-maste-se-over-systemet-for-lss/. Hämtat: 2017-05-29]

Axelsson, T. (2007) Rätt elev i rätt klass. Skola, begånning och styrning 1910-1950 (Linköping Studies in Arts and Science 379). Linköping: Linköpings universitet.

Bacchi, C. (2009) Analysing policy. What's the problem represented to be? French Forest: Pearson.

Bahner, J. (2016) Så nära fär ingen gå? En studie om sexualitet, funktionshinder och personlig assistans (Skriftserien 2016:3). Göteborg: Institutionen för socialt arbete.

Begler, A. \& Lender, A. (2016) Bolag och brukare har fel om kris i assistansen. Dagens Nyheter, den 6 juni 2016. [www.dn.se/debatt/bolag-och-brukare-har-fel-om-kris-i-assistansen/. Hämtat: 2017-11-08]

Brown, W. (1995) States of injury. Power and freedom in late modernity. Princeton, NJ: Princeton University Press.

Carlson, L. (2010) The faces of intellectual disability. Philosophical reflections. Bloomington och Indianapolis: Indiana University Press.

Clement, T. \& Bigby, C. (2010) Group homes for people with intellectual disabilities. Encouraging inclusion and participation. London: Jessica Kingsley Publishers.

Cruikshank, B. (1999) The will to empower. Democratic citizens and other subjects. New York: Cornell University Press.

Dir. 2016:40. Kommittédirektiv: Översyn av insatser enligt LSS och assistansersättningen.

(DPAC) Disabled People Against Cuts. (2014) No money, no food, no heating. Testimonies of disabled people who have had their social security payments stopped. [dpac.uk.net]

Foucault, M. (1990) The history of sexuality. Vol. 1. The will to knowledge. Hammondsworth: Penguin.

Fraser, N. \& Gordon, L. (1997) "Dependency" demystified. Inscriptions of power in a keyword of the welfare state. I: P. Pettit \& R.E. Goodin Contemporary political philosophy. An anthology. Chichester:Wiley.

Försäkringskassan (2016) Hur kan Försäkringskassan bli bättre på att motverka fusk och oegentligheter med assistansersättning? (Socialförsäkringsrapport 2016:8).

Goodey, C.F. (2011) A history of intelligence and "intellectual disability". The shaping of psychology in early modern Europe. Farnham: Ashgate Publishing.

Goodley, D., Lawthom, R. \& Runswick-Cole, K. (2014) Dis/ability and austerity. Beyond work and slow death. Disability \& Society, 29(6): 980-984.

Gottweis, H. (2003) Theoretical strategies of poststructuralist policy analysis. Towards an analytics of government. I: M.A. Hajer \& H. Wagenaar Deliberative policy analysis. Understanding governance in the network society. Cambridge: Cambridge University Press.

Grunewald, K. (2008) Från idiot till medborgare. Stockholm: Gothia Förlag.

Hajer, M.A. \& Wagenaar, H. (2003) Introduction. I: M.A. Hajer \& H. Wagenaar (red.) Deliberative policy analysis. Understanding governance in the network society. Cambridge: Cambridge University Press.

Hill, M. \& Hupe, P. (2002) Implementing public policy. London: Sage Publications. 
Ingram, H., Schneider, A.L. \& DeLeon, P. (2007) Social construction and policy design. I: P.A. Sabatier (red.) Theories of the policy process. Cambridge: Westview Press.

Inspektionen för socialförsäkringen (2014) Assistansersättning och kommunala stöd till personer med funktionsnedsättning (Rapport 2014:19).

Inspektionen för socialförsäkringen (2015) Assistansersättningen. Brister i lagstiftning och tillämpning (Rapport 2015:9).

Johnson, B. (2010) Kampen om sjukfrånvaron. Lund:Arkiv förlag.

Lundquist, L. (1998) Demokratins väktare. Ämbetsmannen och vårt offentliga etos. Lund: Studentlitteratur.

Näsman, M. (2016) Konsekvenser av indragen assistansersättning. En studie om medikalisering och hur kostnader skiftar från samhället till brukaren och dess anhöriga (Umeå Papers in Economic History 46/2016). Umeå universitet.

Olofsson, J. (2009) Socialpolitik. Varför, hur och till vilken nytta? (2 uppl.). Stockholm: SNS Förlag.

Pollitt, C. \& Bouckaert, G. (2004) Public management reform. A comparative analysis. (2 uppl.). Oxford: Oxford University Press.

Prop. 1992/93:159. Stöd och service till vissa funktionshindrade.

Prop. 1999/00:79. Från patient till medborgare. En nationell handlingsplan för handikappolitiken.

Regnér, Å. (2015a) Översyn av lagen om LSS för att tillgodose dagens behov. Svenska Dagbladet, den 10 november 2015. [http://www.regeringen.se/debattartiklar/2015/11/oversyn-av-lagenom-lss-for-att-tillgodose-dagens-behov/. Hämtat: 2018-11-16]

Regnér, Å. (2015b) Viktigt med översyn av LSS. Dagens Samhälle, den 26 november 2015. [https:// www.dagenssamhalle.se/debatt/viktigt-med-oeversyn-av-1ss-20517. Hämtat: 2017-06-06]

Regnér, Å. (2016a) Vi måste kunna prata om kostnader även när det gäller funktionsnedsatta. Nyheter 24, den 9 mars 2016. [http://www.regeringen.se/debattartiklar/2016/03/asa-regnervi-maste-kunna-prata-kostnader-aven-nar-det-galler-funktionsnedsatta/. Hämtat: 2017-1116]

Regnér, Å. (2016b) Välfärden får kosta - men pengarna ska gå till dem som behöver dem. Metro, den 31 mars 2016. [http://www.regeringen.se/debattartiklar/2016/03/valfarden-far-kosta-men-pengarna-ska-ga-till-dem-som-behover-dem/. Hämtat: 2017-11-20]

Regnér, Å. (2016c) Så vill vi förbättra assistansersättningen. Dagens Samhälle, den 26 maj 2016. [http://www.regeringen.se/debattartiklar/2016/05/asa-regner-sa-vill-vi-forbattra-assistansersattningen/. Hämtat: 2017-11-20]

Regnér, Å. (2016d) Kostnadskontroll och utveckling går hand i hand. Dagens Samhälle, den 1 juni 2016. [https://www.dagenssamhalle.se/debatt/kostnadskontroll-och-utveckling-gar-hand-ihand-25451. Hämtat: 2017-11-20]

Regnér, Å. \& Karlsson, A. (2016) Individens rättigheter ska och kommer att stå i centrum. Kristianstadsbladet, den 23 maj 2016. [http://www.regeringen.se/debattartiklar/2016/05/asaregner-individens-rattigheter-ska-och-kommer-att-sta-i-centrum/. Hämtat: 2017-11-20]

Schneider, A. \& Ingram, H. (1993) The social construction of target populations. American Political Science Review, 87(2): 334-346.

Socialdepartementet (2015) Regleringsbrev för budgetåret 2016 avseende Försäkringskassan. (Regeringsbeslut I:8).

Socialstyrelsen (2010) Alltjämt ojämlikt! Levnadsförhållanden för vissa personer med funktionsnedsättning.

SOU 1992:52. Ett samhälle för alla. Stockholm: Allmänna förlaget.

Stubbergaard, Y. (2010) Making citizens. Theories and practices of constructing citizenship 
Socialvetenskaplig tidskrift 2017:2

identities. I: B. Bengtsson, P. Strömblad \& A. Bay (red.) Diversity, inclusion and citizenship in Scandinavia. Cambridge: Cambridge Scholars Publishing.

Walmsley, J. (2005) Institutionalization. A historical perspective. I: K. Johnson \& R. Traustadóttir (red.) Deinstitutionalization and people with intellectual disabilities. London: Jessica Kingsley Publishers. 